\title{
BSA giới thiệu bộ chỉ tiêu đo lường toàn diện năng lực đổi mói sáng tạo
}

Cập nhật ngày: 28/07/2014 05:11:49

Phó Chủ tịch UBND tỉnh Nguyễn Thanh Hùng và đại diện các ngành hữu quan, doanh nghiệp trong tỉnh vừa có buổi làm việc với Trung tâm Nghiên cứu kinh doanh và hỗ trợ doanh nghiệp (BSA) về bộ công cụ I2Metrix.

I2Metrix là bộ chỉ tiêu đo lường toàn diện năng lực đổi mới sáng tạo (ĐMST), giúp doanh nghiệp có cái nhìn thực tế về hiện trạng năng lực ĐMST của mình; đồng thời giúp đơn vị có định hướng rõ ràng và đúng đắn trong việc cần thực hiện điều gì để nâng cao năng lực ĐMST. Bộ công cụ do công ty BSA và Công ty nghiên cứu DHVP Research cùng phát triển và giới thiệu tới cộng đồng doanh nghiệp vào cuối năm 2013. Tính đến tháng 6/2014, đã có 25 doanh nghiệp với quy mô, loại hình khác nhau tham gia chương trình.

Các thông tin của doanh nghiệp khi tham gia I2Metrix được bảo mật hoàn toàn và chi phí khi thực hiện chương trình có 2 mức giá là 5 triệu đồng và 7 triệu đồng.

Phát biểu kết luận tại buổi làm việc, ông Nguyễn Thanh Hùng cho đây là bộ công cụ cần thiết cho các công ty, vì doanh nghiệp không thể tồn tại nếu không ĐMST.

Ong Nguyễn Thanh Hùng đề nghị Sở Công Thương, Sở Khoa học và Công nghệ nghiên cứu tham mưu cho UBND tỉnh để hỗ trợ cho những doanh nghiệp tiên phong trong việc tham gia vào chương trình.

K.D 
